Original Article

\title{
Feral dogs in Chitral gol national park, Pakistan: a potential threat to the future of threatened Kashmir Markhor (Capra falconeri cashmiriensis)
}

\author{
Cães ferozes no parque nacional Chitral gol, Paquistão: uma ameaça potencial para o \\ futuro do Markhor da Caxemira ameaçado (Capra falconeri cashmiriensis)
}

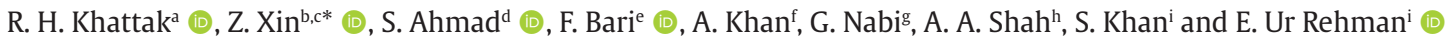 \\ ${ }^{a}$ Northeast Forestry University, College of Wildlife and Protected Areas, Harbin 150040, P.R. China \\ bibrary of Northeast Forestry University, Harbin 150040, P.R. China \\ 'Tarim University, Alar 843300, P.R. China \\ dQuaid I Azam University, Department of Zoology, Carnivores Conservation Lab, Islamabad, Pakistan \\ eUniversity of Chitral, Department of Zoology, Wildlife and Ecosystem Research Lab, Chitral, Pakistan \\ ${ }^{\mathrm{f}} \mathrm{ABD}$ Media, Islamabad, Pakistan \\ gHebei Normal University, College of Life Sciences, Key Laboratory of Animal Physiology, Bichemistry and Molecular Biology of Hebei Province, \\ Shijiazhuang, China \\ hWildlife Department Chitral Division, Khyber Pakhtunkhwa, Pakistan \\ iSnow Leopard Foundation, Islamabad, Pakistan
}

\begin{abstract}
Feral dogs are well-organized hunters of ungulates in many parts of the world, causing great damage to wildlife populations and ultimately to the ecosystem. In Pakistan, the impacts of feral dogs on the wildlife have not been documented yet. In a period of fifteen years (2006-2020), feral dogs have killed hundreds of threatened markhor in Chitral gol national park (CGNP), Pakistan. Despite direct predation other impacts including disturbance and competition with other natural predators, could compromise conservation and management efforts. The population of feral dogs seems to have been increased with the increase of dumping sites by communities. Our findings suggest that there are pressing needs of controlling the feral dogs population and eradicating them from the core zone of CGNP and surrounding buffer communities. Conventional culling of dogs should be coupled with modern techniques like castration and sterilization. Communities should be educated regarding the clean environment, proper disposal of home wastes and, biodiversity conservation.
\end{abstract}

Keywords: Canis familiaris, free roaming, dump sites, Markhor, wildlife loss.

\begin{abstract}
Resumo
Os cães ferozes são caçadores bem organizados de ungulados em muitas partes do mundo, causando grandes danos à população de animais selvagens e, em última instância, ao ecossistema. No Paquistão, os impactos dos cães selvagens na vida selvagem ainda não foram documentados. Em um período de 15 anos (2006-2020), cães selvagens mataram centenas de markhor ameaçados no parque nacional Chitral gol (CGNP), Paquistão. Apesar da predação direta, outros impactos, incluindo distúrbios e competições com outros predadores naturais podem comprometer os esforços de conservação e manejo. A população de cães selvagens parece ter aumentado com o aumento dos locais de despejo pelas comunidades. Nossas descobertas sugerem que há necessidades urgentes para controlar a população de cães selvagens e erradicá-los da zona central do CGNP e das comunidades-tampão vizinhas. $O$ abate convencional de cães deve ser combinado com técnicas modernas como castração e esterilização. As comunidades devem ser educadas sobre o meio ambiente limpo, o descarte adequado de resíduos domésticos e a conservação da biodiversidade.
\end{abstract}

Palavras-chave: Canis familiaris, roaming gratuito, locais de despejo, Markhor, perda de vida selvagem.

\section{Introduction}

Domesticated dogs (Canis familiaris) when escape domestication can become a deadly threat to the local wildlife (Hughes and Macdonald, 2013). These dogs go

through various stages before they become completely wild and independent of humans for resources; based on which various categories are recognized (Vanak and

*e-mail: zhengxin@nefu.edu.cn

Received: November 24, 2020 - Accepted: December 28, 2020 This is an Open Access article distributed under the terms of the Creative Commons Attribution License, which permits unrestricted use, distribution, and reproduction in any medium, provided the original work is properly cited. 
Gompper, 2009). Thus the process of feralization may take considerable time and dogs may actually switch categories based on needs, locality and circumstances (Daniels and Bekoff, 1989; Butler et al., 2004; Vanak and Gompper, 2009). When independent of human derived food, these animals survive on a variety of food, searching and getting food in junkyards, hunting both domesticated and wild animals, and also as scavengers (Manor and Saltz, 2004; Vanak and Gompper, 2009). Communal dump sites provide a strong refuge to feral dogs for successful propagation. In case of increased numbers, they prefer to live in packs having idiosyncratic home ranges like other carnivores (MacDonald, 1983).

Free ranging dogs pose multiple significant threats to wildlife depending on the nature, management and proximity of their location to wild habitats (Vanak and Gompper, 2009). Feral dogs are capable of destructively affecting wildlife via direct predations (Ritchie et al., 2015), competing with other species (Vanak et al., 2015), transmission of diseases (Furtado et al., 2016), fear mediated behavioural changes (Zapata-Ríos and Branch, 2016), and hybridization (Bergman et al., 2009; Bassi et al., 2017). Preying on neonates and juvenile, feral dogs alter population dynamics of wild ungulates (Manor and Saltz, 2004). Some of these threats and their impacts on wildlife are well studied, yet others are less comprehended which indicates that despite being a notable threat and potential predators of wild-fauna; feral dogs have received little attention (Manor and Saltz, 2004; Doherty et al., 2016).

Kashmir markhor (Capra falconeri cashmiriensis), the national animal of Pakistan declared as near threatened globally and endangered in Pakistan (Sheikh and Molur, 2005). The species is endemic to the northern most Chitral district of Khyber Pakhtunkhwa Province, Pakistan. Chitral gol national park (CGNP), situated close to the rural town of Chitral, is a major stronghold of markhor population in the country. Along with other several threats, the markhor population is facing the menace of feral dogs in the national park. Impact of feral dogs on ungulate species is well known particularly as predators of young ones, which changes population dynamics of wild ungulates (Butler et al., 2004; Manor and Saltz, 2004). Despite the long known proliferation of free ranging dogs into the park, their impacts on markhor population has not been assessed in the past. Prevailing situation could result in massive decline of markhor population as well as disrupt ecology of the protected area. Management interventions would be devised based on empirical evidence and prior assessment of the threats. The current study aims to assess and evaluate the impacts of feral dogs on markhor and other associated species of the park and to bridge the existing knowledge gaps pertaining to the issue in the country. Our study provides benchmark data on the impacts of feral dogs on markhor populations in CGNP and recommends mitigation measures.

\section{Material and Method}

The current study was carried out during the period 2006-2020 in CGNP $\left(35.8948^{\circ} \mathrm{N}, 71.6916^{\circ} \mathrm{E}\right)$, encompassing an area of $77.4 \mathrm{~km}^{2}$ (Figure 1 ). Along with markhor, CNGP is home to several threatened species including Snow leopard (Panthera uncia), Himalayan lynx (Lynx lynx isabellinus), Wolf (Canis lupus), Common leopard (Panthra Pardus), Red fox (Vulpes vulpes), and several notable bird species including Golden eagle (Aquila chrysaetos) and Himalayan griffon vulture (Gyps himalayensis).

\subsection{Data collection}

Line transect method was employed for data collection. Five transects each having a length of 5-8 Km length were placed in different locations of the park to scan surrounding

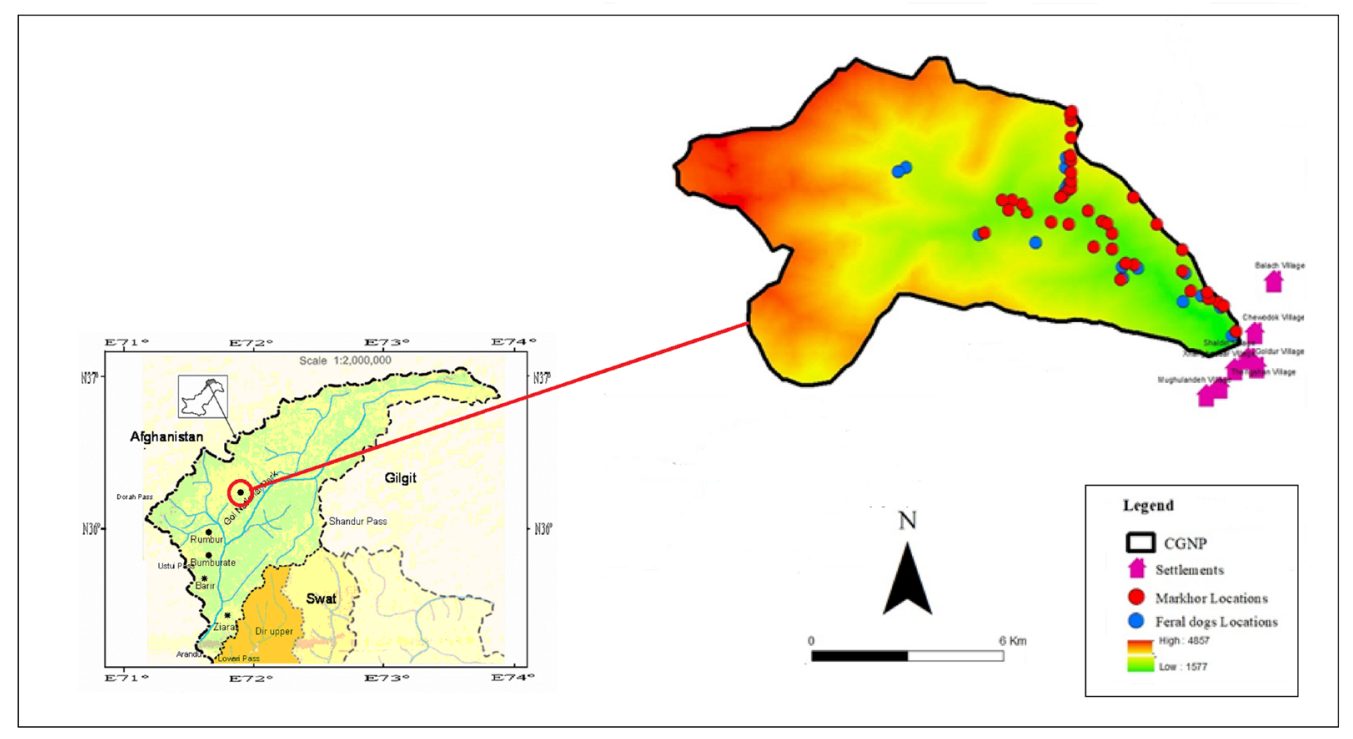

Figure 1. Study area map, depicting markhor and feral dogs observation points along with settlement. 
areas. Standardized data sheets were used to collect direct sightings of feral dogs and associated parameters, while walking on each transect. All the observations were made during ungulate surveys in the park premises. Each event observed, was descriptively recorded and reported accordingly to the repository of Chitral gol wildlife division.

Photographs of live events in real-time were taken by using a drone surveillance camera (DJI-Mavic Pro 2 , Sweden).

\subsection{Statistical analysis}

We used descriptive statistics to calculate the percentage of different impacts by feral dogs. All the calculations were done using Microsoft-excel 2013.

\section{Results}

A total of 997 feral dogs were directly sighted during 15 years with an average of 66 dogs observed per year. Among the 997 dogs 57\% were male 25\% female and the remaining $18 \%$ were puppies and of unidentified sex. Pack size of the sighted dogs ranged from 3 to 18 with a mean size of 6.5 animals per pack (Table 1). Culling of feral dogs started in 2009 and only 9 dogs were shot by the park rangers, 43 dogs were killed in 2015, 53 and 78 dogs were eliminated in 2019 and 2020 respectively.

A total of 941 events were recorded from 2006 to 2020. We broadly classified these events into three major impact categories (Figure 2). The highest percentage (51\%) was recorded for predation followed by disturbance (34\%) and competition (15\%) with other animals mainly for food.
In the predation category, we included all the events ( $n=413)$ during which the feral dogs were observed on hunting with successful kills, chasing markhor or found consuming fresh carcasses of markhor. Disturbance included all those events ( $n=311)$ when the feral dogs were seen roaming in the park or barking at markhor herds from faraway distances. The herds were observed fleeing from the particular site after the occurrence of such an event. In competition, all those events $(n=217)$ were included, where feral dogs were observed for snatching kills from other animals or making other predators flee away from caresses. Such competitive events by feral dogs were recorded with red fox, golden eagles and himalayan griffon vultures.

Results obtained from the current study revealed that a total of 392 markhor had been killed by feral dogs in CGNP (Figure 3). The highest predation was recorded for

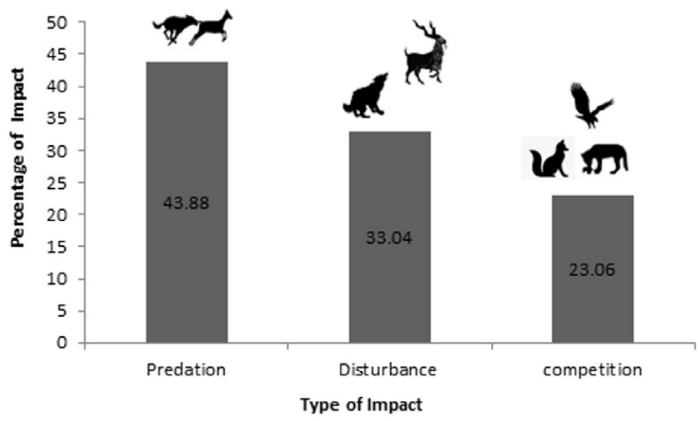

Figure 2. Observed percentage impacts of feral dogs at CGNP.

Table 1. Total count of feral dogs, number of packs with mean size and culled dogs during 2006-2020 in CGNP.

\begin{tabular}{|c|c|c|c|c|c|c|c|}
\hline Year & No of Dogs & Male & Female & Puppy & $\begin{array}{c}\text { Unidentified } \\
\text { sex }\end{array}$ & $\begin{array}{l}\text { Number of } \\
\text { Packs }\end{array}$ & $\begin{array}{l}\text { No of Dogs } \\
\text { Culled }\end{array}$ \\
\hline 2006 & 40 & 26 & 14 & 0 & 0 & 3 & 0 \\
\hline 2007 & 51 & 25 & 12 & 8 & 6 & 5 & 0 \\
\hline 2008 & 57 & 31 & 14 & 11 & 1 & 5 & 0 \\
\hline 2009 & 63 & 36 & 17 & 3 & 7 & 5 & 0 \\
\hline 2010 & 68 & 40 & 15 & 5 & 8 & 5 & 0 \\
\hline 2011 & 74 & 42 & 20 & 11 & 1 & 5 & 0 \\
\hline 2012 & 61 & 38 & 18 & 3 & 2 & 4 & 0 \\
\hline 2013 & 53 & 33 & 12 & 5 & 3 & 4 & 0 \\
\hline 2014 & 69 & 39 & 16 & 10 & 4 & 5 & 9 \\
\hline 2015 & 78 & 47 & 19 & 11 & 2 & 7 & 43 \\
\hline 2016 & 42 & 24 & 9 & 7 & 2 & 3 & 0 \\
\hline 2017 & 58 & 31 & 14 & 12 & 1 & 5 & 0 \\
\hline 2018 & 89 & 49 & 22 & 13 & 5 & 9 & 0 \\
\hline 2019 & 107 & 62 & 26 & 16 & 3 & 15 & 53 \\
\hline 2020 & 87 & 49 & 21 & 14 & 3 & 18 & 78 \\
\hline Total & 997 & 572 & 249 & 129 & 48 & 15 & 183 \\
\hline Mean & 66.46 & 38.13 & 16.6 & 8.6 & 3.2 & 6.53 & ---- \\
\hline
\end{tabular}




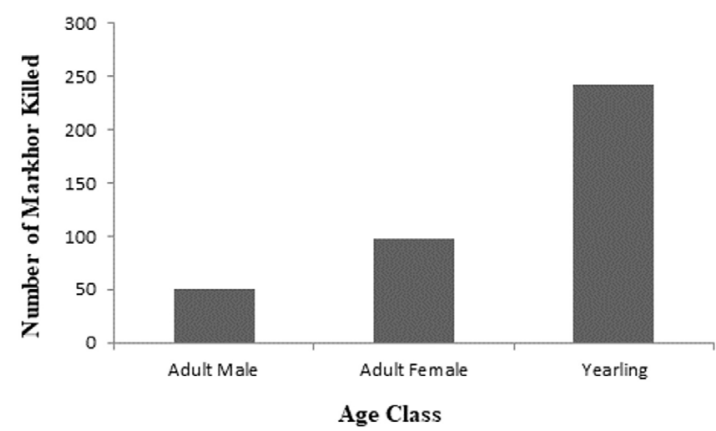

Figure 3. Number and age-wise distribution of markhor killed by feral dogs at CGNP from 2006-2020.

yearlings (61.98\%) followed by adult females (25\%) and adult males (13.01\%).

The results further revealed that with time, the number of feral dogs observed in CGNP has increased, and so markhor depredation. According to the records maintained by wildlife department, a total of 183 dogs have been culled out in 15 years.

\section{Discussions}

In many cases, the impacts of feral dog's depredation are far more drastic as compared to the wild predators (Young et al., 2011). Our study demonstrated that feral dogs are potential predators of markhor in CGNP. Evidence of predation recorded was higher than those of scavenging. Mostly these feral dogs seen at CGNP were in packs (6.5 mean pack size). CGNP harbors a stable population of makhor ( $n=2856)$, as compared to other sites in potential habitats of Chitral district. The habitats where the prey density is high and the feral dogs adopt pack strategy (Figure 4), results in high predation rates (Duarte et al., 2016).

The highest number of yearling predations in CGNP reveals that these feral dogs are similar in hunting patterns to other wild canids, i.e. spotted hyenas (Crocuta crocuta) and African wild dogs (Lycaon pictus) (Duarte et al., 2016). As compared to adult animals, fawns and yearlings are easy and effortless prey for feral dogs. Their strategy is to harass, chase, and distract the young's from their mothers (Figure 5), and prey on them (Muro et al., 2011). Similar depredation results by feral dogs on Mediterranean deer have been reported from southern Spain (Duarte et al., 2016).

Most of the fresh kills by feral dogs at CGNP were found at the bases of cliffs. Although feral dogs are considered potential hunters of ungulates in the steppe (Young et al., 2011), and forested landscape (Silva-Rodríguez and Sieving, 2012). However, based on the inspection reports of predation sites, we assumed that they are capable of adopting hunting strategies like apex predators of the area i.e. snow leopard (Panthera uncia) (Hays, 2018).

Our results also demonstrated disturbances (presence, roaming, and barking) caused by feral dogs in CGNP. Due to such disturbances, the markhor herds were noticed to flee and move towards the higher elevations in the park. The scared herds were not witnessed in their foraging grounds for several days after the occurrence of such

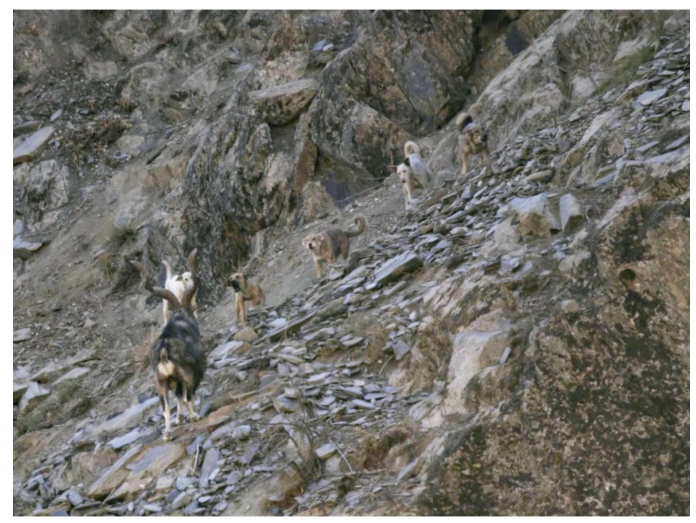

Figure 4. A pack of five feral dogs ready to charge at an adult male.

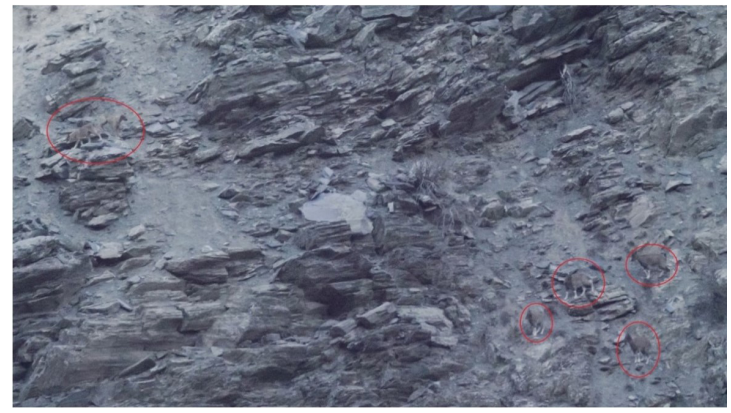

Figure 5. Two feral dogs harassing and trying to distract yearlings from adult female markhor.

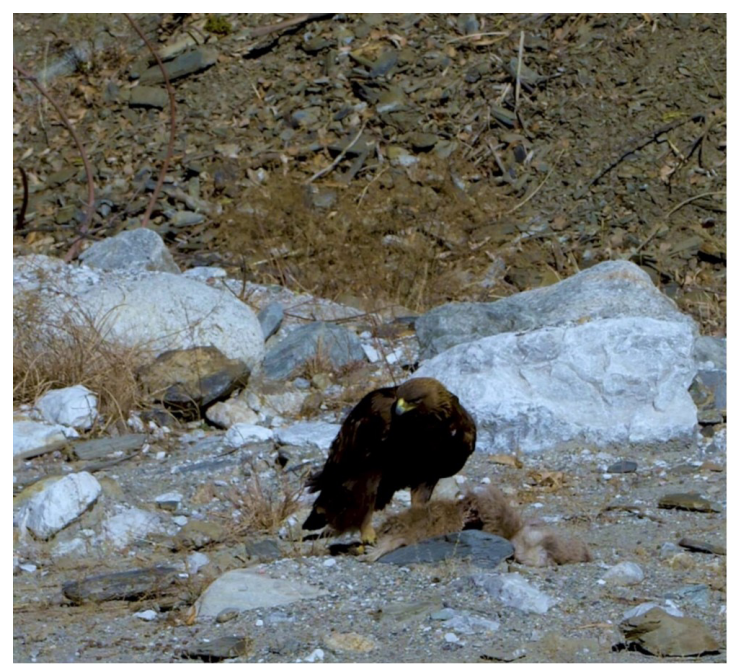

Figure 6. Golden eagle feeding on markhor carcass.

events. Prey species usually had displayed fear-mediated fleeing and escaping behaviour in response to the dog's presence and depredation (Banks and Bryant, 2007; Manning et al., 2014). Furthermore, feral dogs have been observed competing with local predators of the park. In such events, feral dogs were seen chasing away red fox from carcasses. In some cases, feral dogs were observed scavenging, and golden eagles and himalayan griffon vultures were observed hovering over to find any opportunity of feeding (Figure 6). Such competitions by feral 
dogs can cause the extinction of local species in its home range, as it happened with the Tasmanian devil (Sarcophilus harrisii) and Marsupial wolf (Thylacinus cynocephalus) in mainland Australia (Corbett, 1995).

Being a reservoir and vector of rabies, feral dogs have a greater potential of transmitting diseases to wild animals (Butler et al., 2004). Seven villages have been identified as hotspots for feral dogs' viz. Balach, Chewodok, Shaldin, Xhangbazaar, Goldur Thengshan, and Moghulandeh and mostly the entry of these dogs has been observed from these villages. It is pertinent to note that the aerial distance of these villages from the park's boundary is between less than one to one and a half kilometres. The feral dogs of CGNP interact with livestock in the nearby communities, thus can transfer livestock diseases into the wild animals and vice versa. Expansion of human settlements and increased in the number of dumping sites have exponentially increased the number of feral dogs. Another possible and expected threat from feral dogs towards the wildlife is hybridization. The CGNP is home to locally endangered grey wolf (Sheikh and Molur, 2005). Cases of wolf hybridization have been confirmed from Spiti valley, India (Hennelly et al., 2015).

\section{Conclusion and Recommendations}

Our study shows that without any proper control measures, feral dogs had caused significant damage to the markhor population. The population of feral dogs is growing numerically and expanding geometrically in this region. In future these feral dogs can probably cause a more drastic decline to the markhor and other species populations in CGNP. Furthermore, they can pose a serious threat to the local communities and their livestock in terms of disease transmissions. Based on the results obtained in the current study we strongly recommend to:

1. A quick control measures like culling on regular intervals coupled with the neutering of feral dogs, in order to limit their population growth.

2. Regular patrolling parties should be arranged by wildlife department to visit the sites and to monitor the presence of feral dogs.

3. In addition, we strongly recommend conducting community awareness campaigns in the area about cleanliness and proper disposal of wastes.

\section{Acknowledgements}

We extend our cordial thanks to Chitral gol wildlife division, Khyber Pakhtunkhwa, Pakistan; for providing us the data and allowing us to conduct field visits.

\section{References}

BANKS, P.B. and BRYANT, J.V., 2007. Four-legged friend or foe? Dog walking displaces native birds from natural areas. Biology Letters, vol. 3, no. 6, pp. 611-613. http://dx.doi.org/10.1098/ rsbl.2007.0374. PMid:17785262.

BASSI, E., CANU, A., FIRMO, I., MATTIOLI, L., SCANDURA, M. and APOLLONIO, M., 2017. The trophic overlap between wolves and free-ranging wolf $\times$ dog hybrids in the Apennine Mountains, Italy. Global Ecology and Conservation, vol. 9, pp. 39-49. http:// dx.doi.org/10.1016/j.gecco.2016.11.002.

BERGMAN, D.L., BRECK, S.W. and BENDER, S.C., 2009. Dogs gone wild: feral dog damage in the United States. In: Wildlife Damage Management Conference, 2009, Bethesda. Bethesda: National Wildlife Research Center.

BUTLER, J.R.A., DU TOIT, J.T. and BINGHAM, J., 2004. Free-ranging domestic dogs (Canis familiaris) as predators and prey in rural Zimbabwe: threats of competition and disease to large wild carnivores. Biological Conservation, vol. 115, no. 3, pp. 369-378. http://dx.doi.org/10.1016/S0006-3207(03)00152-6.

CORBETT, L.K., 1995. The dingo: in Australia and Asia. Sydney: University of New South Wales Press.

DANIELS, T.J. and BEKOFF, M., 1989. Feralization: the making of wild domestic animals. Behavioural Processes, vol. 19, no.1-3, pp. 79-94. http://dx.doi.org/10.1016/0376-6357(89)90032-6. PMid:24895903.

DOHERTY, T.S., GLEN, A.S., NIMMO, D.G., RITCHIE, E.G. and DICKMAN, C.R., 2016. Invasive predators and global biodiversity loss. Proceedings of the National Academy of Sciences of the United States of America, vol. 113, no. 40, pp. 11261-11265. http://dx.doi. org/10.1073/pnas.1602480113. PMid:27638204.

DUARTE, J., GARCÍA, F.J. and FA, J.E., 2016. Depredatory impact of freeroaming domestic dogs on Mediterranean deer in southern Spain: implications for human-wolf conflict. Folia Zoologica, vol. 65, no. 2, pp. 135-141. http://dx.doi.org/10.25225/fozo.v65.i2.a8.2016.

FURTADO, M.M., HAYASHI, E.M.K., ALLENDORF, S.D., COELHO, C.J., DE ALMEIDA JÁCOMO, A.T., MEGID, J., RAMOS FILHO, J.D., SILVEIRA, L., TÔRRES, N.M. and FERREIRA NETO, J.S., 2016. Exposure of free-ranging wild carnivores and domestic dogs to canine distemper virus and parvovirus in the Cerrado of Central Brazil. EcoHealth, vol. 13, no. 3, pp. 549-557. http:// dx.doi.org/10.1007/s10393-016-1146-4. PMid:27469023.

HAYS, J., 2018. Snow leopards: characteristics, hunting behavior, humans and poaching. Facts and Details.

HENNELLY, L., HABIB, B. and LYNGDOH, S., 2015. Himalayan wolf and feral dog displaying mating behaviour in Spiti Valley, India, and potential conservation threats from sympatric feral dogs. Canid News, vol. 624.

HUGHES, J. and MACDONALD, D.W., 2013. A review of the interactions between free-roaming domestic dogs and wildlife. Biological Conservation, vol. 157, pp. 341-351. http://dx.doi. org/10.1016/j.biocon.2012.07.005.

MACDONALD, D.W., 1983. The ecology of carnivore social behaviour. Nature, vol. 301, no. 5899, pp. 379-384. http://dx.doi. org/10.1038/301379a0.

MANNING, J.K., FOGARTY, E.S., TROTTER, M.G., SCHNEIDER, D.A., THOMSON, P.C., BUSH, R.D. and CRONIN, G.M., 2014. A pilot study into the use of global navigation satellite system technology to quantify the behavioural responses of sheep during simulated dog predation events. Animal Production Science, vol. 54, no. 10, pp. 1676-1681. http://dx.doi.org/10.1071/AN14221.

MANOR, R. and SALTZ, D., 2004. The impact of free-roaming dogs on gazelle kid/female ratio in a fragmented area. Biological Conservation, vol. 119, no. 2, pp. 231-236. http://dx.doi. org/10.1016/j.biocon.2003.11.005.

MURO, C., ESCOBEDO, R., SPECTOR, L. and COPPINGER, R.P., 2011. Wolf-pack (Canis lupus) hunting strategies emerge from simple rules in computational simulations. Behav. Behavioural Processes, vol. 88, no. 3, pp. 192-197. http://dx.doi.org/10.1016/j. beproc.2011.09.006. PMid:21963347.

RITCHIE, E.G., DICKMAN, C.R., LETNIC, M. and VANAK, A.T., 2015. Dogs as predators and trophic regulators. In: M. E. GOMPPER, 
ed. Free-ranging dogs and wildlife conservation. Oxford: Oxford University Press, pp. 55-68.

SHEIKH, K. and MOLUR, S., 2005. Status and red list of Pakistan's mammals, based on conservation assessment and management plan for mammals. Pakistan: IUCN, $344 \mathrm{p}$.

SILVA-RODRÍGUEZ, E.A. and SIEVING, K.E., 2012. Domestic dogs shape the landscape-scale distribution of a threatened forest ungulate. Biological Conservation, vol. 150, no. 1, pp. 103-110. http://dx.doi.org/10.1016/j.biocon.2012.03.008.

VANAK, A. and GOMPPER, M., 2009. Dogs Canis familiaris as carnivores: their role and function in intraguild competition. Mammal Review, vol. 39, no. 4, pp. 265-283. http://dx.doi. $\operatorname{org} / 10.1111 / \mathrm{j} .1365-2907.2009 .00148 . x$.
VANAK, A.T., DICKMAN, C.R., SILVA-RODRIGUEZ, E.A., BUTLER, J.R.A. and RITCHIE, E.G., 2015. Top-dogs and under-dogs: competition between dogs and sympatric carnivores. In: M. E. GOMPPER, ed. Free-ranging dogs and wildlife conservation. Oxford: Oxford University Press, pp. 69-93.

YOUNG, J.K., OLSON, K.A., READING, R.P., AMGALANBAATAR, S. and BERGER, J., 2011. Is wildlife going to the dogs? Impacts of feral and free-roaming dogs on wildlife populations. Bioscience, vol. 61, no. 2, pp. 125-132. http://dx.doi.org/10.1525/bio.2011.61.2.7.

ZAPATA-RÍOS, G. and BRANCH, L.C., 2016. Altered activity patterns and reduced abundance of native mammals in sites with feral dogs in the high Andes. Biological Conservation, vol. 193, pp. 9-16. http://dx.doi.org/10.1016/j.biocon.2015.10.016. 